LA-UR- $95=381$

Title:

\title{
PLAN FOR INCREASING PUBLIC PARTICIPATION IN CLEANUP DECISIONS FOR THE LOS ALAMOS NATIONAL LABORATORY
}

Author(s):

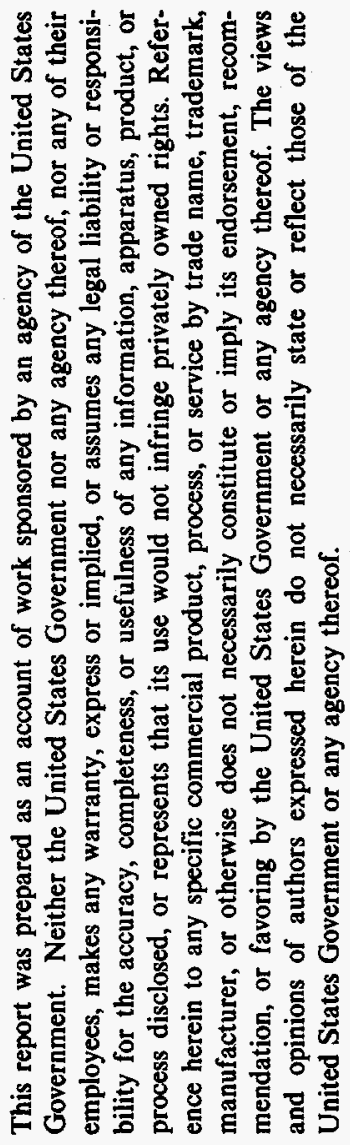

\section{Working Group for Public Participation in Cleanup Decisions with the assistance of Merle Lefkoff \& Associates}

Submitted to:

\section{The general public}

\section{Los Alamos}

NATIONAL LABORATORY

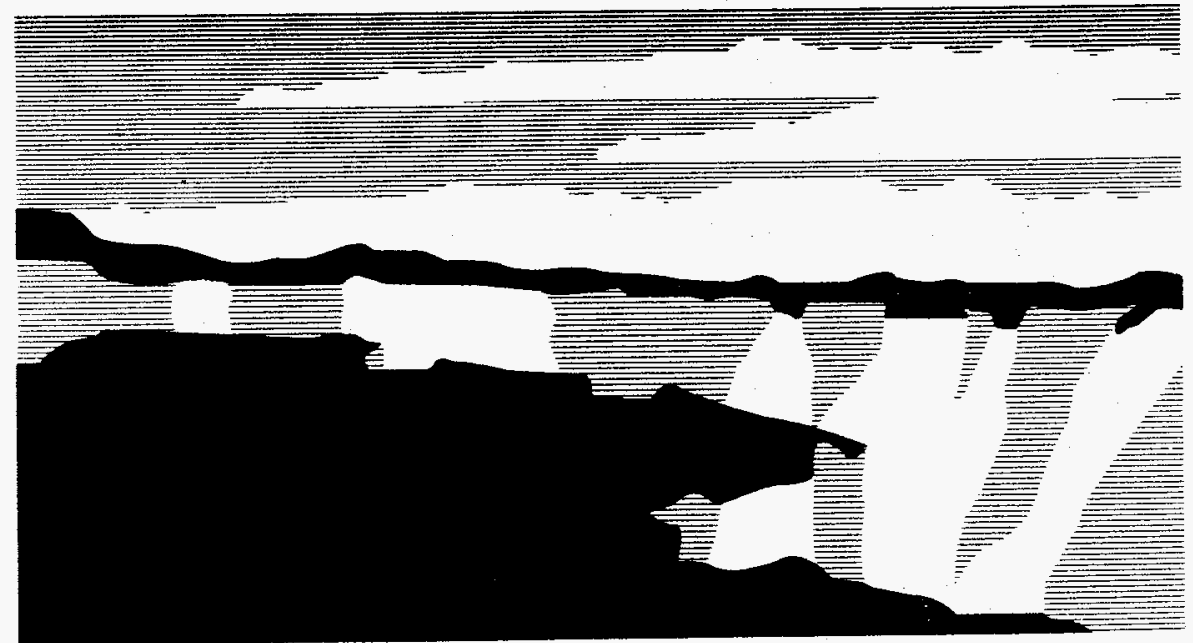

Los Atamos National Laboratory, an affirmative action/equal opportunity empidyer, is operated by the University of California for the U.S. Department of Energy under contract W-7405-ENG-36. By acceptance of this article, the publisher recognizes that the U.S. Government retains a nonexclusive, royalty-free license to undelish or reproduce the published form of this contribution, or to allow others to do so, for U.S. Government purposes. The Los Alamos Nationai Laboratory publish or reproduce the published form of this contribution, or to allow others to do so, for U.S. Governments the publisher identify this article as work performed under the auspices of the U.S. Department of Energy. 


\section{DISCLAIMER}

Portions of this document may be illegible in electronic image products. Images are produced from the best available original document. 
LA-UR-

\title{
PLAN FOR INCREASING PUBLIC PARTICIPATION IN CLEANUP DECISIONS FOR THE \\ LOS ALAMOS NATIONAL LABORATORY
}

\author{
Environmental Restoration Project \\ Environmental Management Program Ofice
}

\author{
Prepared by the \\ Working Group for Public Participation in Cloanup Decisions \\ with the asaistance of \\ Merie Lefkoff \& Associntes
}




\section{BACKGROUND}

This document describes a plen for involving the publlc in decialons roleted to cleaning up attes suspected of being contaminated with chemicals or radiosctivity at Los Namos National Laboratory (the Laboratory). The Laboratory's Environmental Restorotion (ER) Project has responsiblity for conducting this cleanup. In this section, we describe the purpose of the ER Project, our past efforts to communicate with the northem Now Mexico community, and the events that brought about our realization that less traditional, more innovative approsches to public involvement are needed.

At the same time, agencies such as the Environmental Protection Agency (EPA) and the Department of Energy (DOE) are encouraging federal facilitios such as this Laboratory to involve the public eartier in decision-making processes and to be much more responsive to public concerns. Thus, the objectives of this plan dovetail with the princlples being promoted by EPA and DOE.

As used in this plen, "public" means the general public, Laboratory employees not directly involved in the ER Project, representatives of government agencies and elected bodies, and others interested in or affected by the ER Project. These individuals are ofton called "stakeholders." Although we are imiting members of Indian pueblos to participate in the activities described in this plan, the pueblos located near the Laboratory are being involved through a separate "governmentto-govemment" process established under recent cooperattve agreements between the Laboratory and three of the pueblos.

We understand that arriving at new and effective processes and bullding mutual trust will take time, patience, and persistence on the parts of both the ER Project and the public. Our purpose in developing this plan with the public is to begin to build that trust and discover alternatives for cleanup that are acceptable to all interested parties based on their imolvement in developing recommendations for cleanup.

\section{The Environmental Reatoration Project}

In 1989, the Laboratory established the ER Project to identify the extent of contamination in and around the Laboratory and the appropriate means of cleaning it up. The project responds to the requirements of the federal Resource Conservation and Recovery Act (RCRA) and its Hazardous and Solid Waste Amendments (HSWA). RCRA governs the day-to-doy operations of hazardous waste generation, treatment, storage, and disposal and established a pormitting system under which hazardous waste facilities must operate. HSWA modified the permiting sections of RCRA by specifying that federal facilities' operating permits contain fecility-epecilic cleanup programs to address past contamination problems involving hazardous waste. Module VII (the HSWA Module") of the Laboratory's RCRA permit responds to this requirement. The EPA is the primary regulatory agency that enforces the HSWA Module, and the New Mexico Environment Department (NMED) has the primary enforcement authority for the remainder of the RCRA permit.

The HSWA Module contains a list of sites, called solid waste management units (SWMUs), which are suspected of releasing hazardous contamination to the environment. This fist was developed by the Laboratory and approved by EPA. Sites suspected of containing radioactive contamination are not addressed by RCRA and are not included on the list in the HSWA Module. However, the ER Project is cleaning up these sites, along with the SWMUs, in accordance with applicable DOE orders. SWMUs and sites suspected of containing radioactive contemination are collectively called potential release sites (PRSs). Our objective is to investigate each PRS and to take action that will bring the PRS to an acceptable standard of risk. 
The Laboratory follows the three-step cleanup process mandated by the HSWA Module. The first step-the RCRA facility investigation (frequently called an RFI)-is dealoned to identify the presence or absence of contamination (Phase $l$ of the investioation). Based on the reaults of Phase 1, the ER Project may recommend no further action, even though contamination below acceptable risk levels is present. However, if contamination is present above apecilied lovele, the investigation moves to Phase II. Several different options are available in Phase II, Including further investigation and expedited deanup. The results of Phase I and II investigatione are summarized in RFI reports.

If the RFI indlcates that further action is required, the project proceeds to the cecond step-a corrective measures study (CMS)- to evaluate cleanup alternatives. The study will conaider riaks to human health and the environment, coets, and other factors such as disposal methods. The third step-corrective measures implementation (CMI)-carries out the chosen corrective mensure, verifies its effectweness, and proposes control and monitoring procedures.

The ER Project proposes actions and remedies to EPA and DOE based on ins invostigations. EPA makes the final decision on hazardous waste sites based not only on the documentation of the cleanup but also on the public's opinion of the ER Project's recommendation. For example, when the ER Project proposes to remove a site from the list in the HSWA Module, if must go through a formal permit modfication process that includes a public hearing. This ia the only point in the process at which EPA requires public comment. In addition, NMED actively reviews the work of the ER Project and may eventually receive authority from EPA to enforce the HSWA Module.

Factors to be considered in the decision-making process for cleaning up PRSs include the amounts and kinds of waste to be cleaned up, cleanup costs, public concams, disnuption of the physical environment, and possible future uses of the remediated sitea, such as residential, recreational, and continued Laboratory use. These factors may lead to different alternattves, such as leave the waste in place, stabilize the waste, move it to a Laboratory disposal ares, or transport it of the Laboratory site. Each of these factors and alternatives carries different soclal, economic, and environmental consequences.

Determining land use alternatives is important because these allernatives are fundamental to making decisions on how much cleanup needs to be done. Because some future uses of land (such as residential) require more cleanup than others (such as recrestional), deciding on appropriate land use altematives early in the cleanup process is a smart way of doing business. Because determining land use altematives and making decisions on the level of cleanup are intertwined, both processes must include earty and meaningrul public input.

\section{PAST PUBLIC INVOLVEMENT ACTIVTIES OF THE ER PROJECT}

In 1991, the ER Project began its outreach to the public. We prepared information sheets on contaminated areas, sponsored querterly public information meetings, and developed a mailing list of approximately 1,800 individuals so that we could distribute a quarterty newsletter and inform these people of public meetings and other events. Our activities also included occasional tours, briefings for local organizations, and public involvement training for ER Projoct staff. We were disappointed in public participation in these events and formed a working group to find more effective means of communicating with the public.

In February 1994, the working group invited members of the public to brainstorm intormally about ways of obtaining more effective public participation. Out of that meeting came three important suggestions: (1) We need to involve the public in a dialogue instead of just handing out information 
at public meotings and asking for public comment on "finishod drafta" (2) We should avoid reinventing the wheel by reviewing public imvolvement efrots at other sites around the country. (3) We should conduct a pilot project as a way of developing more effective public participation.

We accopted the first two of suggestions, and the following sections deacribe how wo hove responded. Atthough we began by developing a draft plan for a plot public particlpation project at a single Laboratory site, we have come to believe that applying the drail plen to the entire project will allow earller, more meaningtul public involvement than would have occured in the pllot approach.

In developing an approach to public participation, the working group retiected on comments made by the public at the Fobruary 1994 meeting. One member of the public etated that the ER Project must deal with the "suspicion that environmental restoration actlitiles will serve as a cover for generating and handling more waste." Another said, "There are too many meetings and they are too long." Yet another said, "The public doesn't feel technicaly literate or competent to judge the technical information that comes our way." Finally, "Citizens have strong ldeas about how public participation should be done."

Based on this input, we went out to the northern New Mexico to obtain information for planning purposes and to begin a dialogue with the community. Teams of ER technical staff and experienced interviewers went into the community to listen and respond to the public.

During the interviews, we received comments on how to solve the historic problems of lack of lrust and the traditional, one-way manner of providing technical information. In response to the question, "Tell us what you think are the most important things to be considered in setting up an effective public participation process," interviewees offered many thoughtful cuggestions:

- make information easily readable (don't use jargon),

- go out into the communities to present information at informal meetings (for example, at meetings of existing community groups),

- make public involvement efforts consistent throughout the Laboratory,

- include the public in the decision-making process by providing more opportunities for interactions with decision makers and technical personnel,

- show ER work in progress (through site tours, for exampla), and

- be sensitive to ethnic and cultural concerns.

Major issues and concerms of the interviewees included

- trust, honesty, and openness;

- positive economic impact of the Laboratory on northem New Moxico;

- environmental health concerns:

- effective public participation in environmental restoration;

- impacts of the Laboratory on the community's social structure and culture;

- cleanup issues; and

- awareness and knowledge of the ER Project.

Many issues were related to trust, honesty, openness. Thitty-two of the 43 interviewees mentioned items related to these issues, either speaking about their personal opinions or how they felt the community perceived this issue. One interviewee urged openness and noted that the sense of secrecy at the Lab makes the public distrustful. Nevertheless, people expreseed positive feelings about Laboratory personnel on an individual, human level and about their scientific expertice. Others said, "Take me seriously." "Be up front." "Share relevant information." - 
We believe that the interviews resulted in a genuine dialogue and began the process of building personal relationships between Laboratory employees and the public. Resction from both the community and the interviewers supported the decision to involve technical people in the interview process. Interviewers reportod, "A lot of excitement was genereted duing my interviews. Thls should be part of my job: one hour a woek talking with the peblic." "Eoth inteviewers and interviewees foll the comfort level generated by the contact." Wh are sharing the interview report. which describes how the survey was constructed, how the interviews were conducted, and how the responses were analyzed, with all who participeted in the interview process (Appendbx A of this plan).

A review of public involvement programs at other sites around the country reveals strong and consistent guiding principles, which correspond closely lo comments recelved during our interviews of June and 1994. (Appendix B provides a more detailed description of site programs and literature about public involvement.) Some of the principles gleaned from this review are summarized below:

- In building public Irust, the facility must reach out to groups and individuals outside those who have historically taken the initiative to become involved in issues anlecting the facilly.

- Meaningful, interactive dialogue must replace tradtional presentation formats and one-way information giving.

- Interested groups and individuals must be involved in the decislon-making process early enough to allow decision makers to amend, modify, andlor dovelop decisions that reflect public input.

- Involving the public in decision making must be a positive, long-term way of doing business.

\section{Other Cloeely Rolated Activities at the Laboratory}

In 1994, the Los Alamos Area Office of DOE and the Laboratory undertock a joint initiative called the Future Site Use Planning Initiative and appointed a team to coordinete stio, facilitios, environmental, and strategic planning. The goals of future she use planning are to

- identify land and facilities needed for current and future missions of the Laboratory:

- identify opportunities for leasing or transferring surplus land and ficillias to other federal agencies; tribal, stato, and local governments; and the private sector, and

- provide opportunities for meaninghul stakeholdar involvemem in these plens.

By December 1995, the integration team must deliver to DOE

- background, including site information and processes used to implement these goals;

- site-planning assumptions; and

- future use options and scenarios preferred by stakeholders.

\section{GOALS AND OBJECTIVES OF OUR PUBLIC PARTICIPATION PLAN}

We have developed the plan's philosophy, direction, and activities with an cye to the concerns expressed during the interviews. The goals of this public participation plan are to 
- brosden the base of involved individuab and groups beyond those previoualy involved in the ER Project, including employees of other Laboratory organizattons;

- begin to build trust by focusing on personal contact, dialogue, and mutual education;

- obtain meaningtul public hput in decisions regarding clesnup lavues; and

- learn a better, more cost-effective way of involving the public early in the ER Project.

The specific objectives of this public participation plan are to

- give the public the information it needs to understand ER cleanup issues and provide informed input.

- make information readily available to the public,

- increase contacts with the public in woys that encourage interaction,

- involve the public in the cleanup process before decisions are made,

- coordinate public involvernent activities for the ER Project with those conducted for the Future Site Use Planning Initiative,

- develop criteria for defermining whether an area is a reasonable candidete for other than residential use, and

- evaluate the effectiveness and efficiency of each of the public participation activities.

\section{PUBLIC PARTICIPATION PLAN}

As stated in Section 1, the regulatory process requires the ER Project to imestigate a site, analyze the data, and then, based on the analysis, develop recommendations. These recommendations include cleanup actions and recommendations for no further action. Factors in cleanup decisions include the amounts and kinds of waste to be cleaned up, the types of technologies to be used. pubfic concerns, and the desired degree of cleanup. Cleanup actions may themseives disturb the environment and will produce wastes. Tax dollars spent in cleanup must also be considered. We need the public's help in weighing these factors for cleanup decisions.

The HSWA Module provides a staggered cchedule for cleaning up the approximately 2,100 PRSs at the Laboratory; thus, not all PRSs are in the same stege in the cleanup procose. At some sites, we have already recommended no further action, and a permit modification requeat has already been developed that contains these recommendations. We will discuss the proposed permit modilication request and invite public comment at as many opportunities as poselble in the time allowed by EPA for the permit modification. These opportunities incude a round table meoting, sibe toura, a public hearing, and invitations to speak with interested groups and citzens. The ER Project will make technical staff available to discuss the history and background of PRSs in the current request for permit modification. to describe the sampling and the data obtained on PR8s of interest, and to describe the risk assessment process and its relationship to various alternatives.

As recommendations for other PRSs are developed in the future, we will involve the public much earlier in the process. We will also discuss with the public the ramifications of cleanup to residential. recreational, and industrial standards and whether different standards should be applied to individual areas or the same standard to all of a given geographic area. Along with the public, we will attempt to develop criteria for determining appropriate cleanup standards and use these criteria to arrive at recommendations. We will also ask the public to help us develop a system for prioritizing sites. 
Recently, the Laboratory signed cooperative agreements with Cochiti. Jemez, and San Iddefoneo pueblos and expects to sign a similar soreement with Santa Clara Pubblo. The agreements establish an implementation team that includes representatives from esch pueblo and varlous Laboratory organizations. The implementation team will hold monthly meetings to docuss lasues ralsed by any of the parties, and the Laboratory will propose the lasue of cleanup decisions in the ER Project as one of these isues. The specific mechanisms for involving the pusblos in the ER Project will be determined under the cooporattve agreements.

The cections below provide descriptions of the specific activities wo prepose to use to implement this public partleipation plan.

\section{Working Group Mootings}

The working group will meet as necessary to review progress and to coordinate with other Laboratory organizations involved in related activities (such as the Stakeholder Involvement Ofirice. future site use planning group, and ER Project leaders). To ensure a public perspective at the working group meetings, we will invite people who have said that they would be intereated in following this process. The working group will also expand representation of ER Project personnel to reflect the broader scope of the public participation plen.

\section{Proparing Information on the ER Project}

We are preparing a variety of materials for the northem New Mexico community, including the public schools. The materials consist of newrletters, progress reports, and information sheets that include site maps, extent of contamination, and remediation altematives. To make these moterials more understandable, informative, and sensitive to cultural issues, we will preteat them with the public. Printed materials will be transtatod into Spanish. If the pueblos indicate a desira for an oral translation, we will arrange for presentations in pueblo languages. We will also explore developing a computer-aided system for libraries, the Laboratory's Community Reading Room, and personal computers, which would allow the public to ask questions and receive answers about the ER Project.

\section{Roundtable Meeting with Interviowees, Interviowers, Other Invitees, and Working Oroup}

In February 1995, we are holding a roundtable meeting to give interviewees a chance to discuss the interview process and how well the process is reflected in the plan. It will also provide an opportunity for individuals to decide whether they would like to participate in other aspects of the pilot project, such as tours, educational activities, and development of cleanup criteria. Their comments will be added to this plan. We will ask participants to sugoest appropriate community groups for outreach and to identify community leaders who should bo involved. In addition, we will describe the ER Project and the status of cleanup decisions. The dialogue will be important, as were the interviews, for building trust that two-way listening is occurring.

\section{Joint Training for ER Project Personnol, Working Group, and Interested Publle}

Part of the roundtable meeting will consist of training in communication skills, including training in sensitivity to northem New Mexico cultures, for individuals both ineide and outside the Laboratory who have expressed interest in the public participation plan. 


\section{Disseminatlon of Information}

The major objective of all information dissemination is to famillarize the public with the ER Project so that they may participate knowledgeably. To ensure that we can reach al interested parties, we will continue to develop and maintain a contact list. Anyone who desires information about the ER Project may call the Laboratory's Stakeholder Imvolvement Ofice, toll-free, of 1-800-845-4600 to get a response from someorie involved in the project. This number will be published in many places. We also plan to distribute written information to a variety of locations where the public is llkely to see it, such as stores, doctors' offices, llbraries, schools, and town bulletin boards.

\section{Community Meetings}

We will solicit invitations from community groups to attend thelr meetings for the purpose of sharing information and discussing the ER Project and public participation in the project, targoting such groups as traditional clubs, acequila associations, land assoclations, coops, the pueblos, Laboratory employees, and church groups. The primary goals of these meetings will be personal engagement and informal group dialogue. Ideally, a two-person bam consisting of a technical representalive of the ER Project and an individual from the public affiliated with the community group being visited will attend these meetings. We will ask participants to suggest others who might be interested in participating.

\section{Toure of Environmental Revtoration Sites}

Tours will help acquaint the public with the ER Project and specific PRSs sddreseed in the current and future requests for permit modifications. Times convenient for the public will be a primary consideration in scheduling these tours. To supplement the discussions churing the fours, we will distribute briefing packets. These tours, which are open to all members of the public interested in participating, will be offered after the roundtable and after other activities at which people have been asked to identify others who may be interested in participating. We will ask tour participants to volunteer for further involvement in the public participation process. As the process proceeds, site tours will focus on specific PRSs. To guide future planning and to aid in evaluation, we will record concems and suggestions.

\section{Education Programs}

Our staff continues to be available to visit schools and to help teachers who request assistance in developing class projects that promote students' understanding of and involvement in the ER Project Such assistance has been enthusiastically received in the past, and we would like to expand this service. We will work with the Laboratory's Science Education and Outreach Group to develop programs for students. -

\section{Public Input to Recommendations for Cleanup}

Throughout the public participation process, we will ask people whether they would like to participate more actively in developing criteria for cleanup decisions and will invite such people to working meetings for this purpose. If we get a large response, we work with all volunteers to develop a fair mechanism for selecting a workable number of participants. The documentation of this process will be sent to EPA as part of the request for permit modification, along with the record of the formal hearing on the permit modification. 


\section{EVALUATION}

To determine the success of the public participation effort, we must thoroughly evaluate the activities againat the goals and objectives establishod in Section 3. Whenover public participants are present at the activity being evaluated, we will devote a portion of that activity's time to ovaluation. Beginning with the roundtable, we will obtain input from the public and ER Project personnel on the goals and objectives of each activily. An objective evaluntor (a person not involved in other public Involvement activities) will compile the responses. This method of evaluation will allow the people who are most involved in the public participation effort to have the etrongest say in whether it has achieved its goals.

The evaluations will measure the extent to which we have broadened the base of Involved Individuals, have begun to build trust, and have obtained meaningful input into ER Project decisions. The evaluation will also measure the extent to which we have learned more cost-effective ways of involving the public in cleanup dectsions. Other measures will consider the ER Project's sensitivity to public input in the decision-making process and the regulators' response to decisions that incorporate public input gamered through this procese.

The informal interviews conducted in June and July 1994 provide baseline data on public attitudes toward, and trust in, the ER Project. We will conduct similar interviews to evaluate the efiects of the revised approach to public involvement. II is important to keep in mind that many of the attitudes and perceptions monitored, such as the public's confidence and level of trust in the integrity of ER Project personnel, change slowly and changes may not be detectable for several years.

Documents prepared for the public, including translated materials, will be analyzed for clarity and ability to increase the public's interest in and understanding of cleanup issues.

We will use brief questionnaires to evaluate the coinions of the public and ER personnel regarding the effectiveness of this effort in achieving the following goals: (1) increase public interest in the ER Project, (2) increase ER Project understanding of public concerns, (3) increase public understanding of the ER Project, and (4) build relationships between the ER Project and the community.

In addition. we will collect observational data to complement these analyses. For example, recording attendance at each event will show the time commitments made by members of the public, as well as allow some quantification of the opportunities created for dialogue.

Finally, we will pertorm a traditional costbenefit analysis of this public participation process. The costs (such as stafing costs to participate in community meetings and to prepare information sheets) can be quantified and summed to astimate the cost side of the equation. On the other alde, benefits (such as having public input early 80 that the likelihood of public opposition to proposed permit modifications is reduced) are very difficult to quantify. Many of the benefits will occur over long periods, will be very subtle, and will be difficult to value in monetary terms. Despite these difficulties, we will attempt to estimate the dollar value of benefits so that a costbenefit analyais can be performed as another means to determine whether tax dollars spent on this public participation effort have been spent effectively. 


\section{APPENDIX A}

\section{RESULTS OF COMMUNITY INTERVIEWS TO ASSIST IN THE DEVELOPMENT OF A \\ PILOT PUBLIC PARTICIPATION PLAN FOR ENVIRONMENTAL RESTORATION CLEANUP DECISIONS}

\section{SURVEY OVERVIEW}

\section{Background}

To help develop a more effective public participation plan for the Environmental Restoration (ER) Project at Los Alamos National Laboratory (the Laboratory), teams of interviewers, consisting of an experienced interviewer and a technical person from the ER Project, interviewed 43 residents of northern New Mexico. These discussions were informal conversations based on a standard set of questions. between citizens of northern New Mexico, and an interview team consisting of technical staff from the Laboratory, and an experienced interviewer. We felt that this approach, rather than conducting formal surveys, would provide us with better qualitative information and would better serve the public involvement process. The approach and the topics we covered were similar to those included in interviews at other Department of Energy (DOE) sites; however, we observed that including technical staff as part of the interviewing team enriched the information received from the interviewees and that the conversations themselves created some excitement and healthy expectations about this process.

The interviews provided information about the impact of the Laboratory on the respondents' community, assessed respondents' awareness and knowledge of the ER Project, identified issues that concerned the interviewees, and explored interviewees' ideas about how to encourage community participation in the public involvement components of the project. Most importantly, the interviews broadened the dialogue between the ER Project staff and the community. Several respondents reported that this was their first face-to-face conversation with the ER Project staff, although public meetings involving ER staff and interested citizens have occurred since 1991.

Geographically, the interviewees came from Taos, Española, Los Alamos, and Santa Fe, and surrounding communities. Selected for their diversity and community involvement, the respondents included elected officials, agency staff, ethnic and peace organizations, the media, educators, representatives of business, and other interested citizens. Twenty-four respondents were male and 17 female; 21 were Anglo, and the other 20 were mostly Hispanic. Respondents ranged in age from their late 20s to over 60; most of the respondents were in their 40 s and 50s. We began interviewing on June 29 and finished on July 13, 1994. 


\section{General Impresslons}

Interviewees' responses to the interviews showed that the very process of beginning a dialogue between the Laboratory and the community was beneficial. At least 6 of the 43 respondents specifically mentioned the positive impact of talking with a technical person from the Laboratory about Laboratory issues. Also, most of the technical interviewers found their involvement to be a very rewarding experience. Nearly all respondents seemed positive about the time they had contributed to the effort, including current and former employees of the Laboratory, vocal opponents of the Lab, and those in the middle.

Another impression conveyed in many interviews was that sensitivity to the cultural diversity of the region is important as is involvement of native peoples, both Hispanic and Native American. The latter is a real issue for the Hispanic respondents as well as for others.

\section{CONCERNS OF THE COMMUNITY}

The respondents were keenly aware of the Laboratory's profound economic and social impact on northern New Mexico. The extent of this awareness pervades many respondents' comments, whether they are supportive of, or antagonistic toward, the Lab. Thus, the issues and concerns raised in the interviews relate not only to the ER Project but to the Laboratory as well. Every respondent spoke of the Lab and/or its public involvement process, but not all respondents knew about the ER Project. Many respondents also noted the distinct cultural diversity of the area around the Lab. It is clear that involving people who are indigenous to this region requires sensitivity and understanding of cultural differences.

\section{ISSUES AND CONCERNS ABOUT THE LABORATORY}

\section{Positive Economic Impact of the Laboratory on the Community}

Thirty-two of the 43 respondents specifically mentioned the positive economic impact on northern New Mexico, and two others mentioned it with mixed feelings about whether this impact is positive. Clearly the issues of jobs, employment, and overall economic impact are in the minds of the respondents when asked to think about the Lab.

\section{Trust, Honesty, and Openness}

A second significant theme, and one that is a real challenge for designing and carrying out a successful public participation effort, is a cluster of issues relating to trust, honesty, and openness. Thirty-two of the 43 respondents mentioned issues related to trust, honesty, and openness, although some of the 32 respondents were expressing concerns of their organizations and communities rather than their own. All 32 respondents focused on these issues as a problem for public involvement in northern New Mexico. One respondent expressed a 
"reasonably confident" opinion of the ER Project but urged openness and noted that the culture of secrecy at the Lab makes the public distrustful. One negative comment charged the Lab with harboring a "culture of arrogance." Another interviewee said, "Take me seriously," and one person said, "Be up front, share relevant information." Yet another respondent, who felt confident of the thoroughness of any cleanup, asked, "Where does the waste go? Are you just creating another problem?" It is clear from the interviews that the Laboratory must deal proactively with the issues of trust and open communications part of any public involvement process.

\section{Environmental and Health Concerns}

When asked about the impact of the Laboratory on their community, 25 respondents mentioned the negative impact on the environment. The two most frequent concerns were radiation-cesium and plutonium were specifically mentioned-and health issues. Some interviewees expressed fear about safety, based in part on what had happened to members of their families. Many respondents reported that contamination of water, especially aquifers, concerned them, and three respondents expressed concern with waste and waste disposal. Two respondents noted contamination, especially in canyons, as an issue. Some respondents reported concern over the unknown extent of contamination as a result of the Laboratory operations; although one interviewee felt that environmental issues are exaggerated by activists. Clearly, when residents think of the positive and negative impacts of the Laboratory on their community, environmental issues are the negative impact most frequently mentioned. Some interviewees who were largely uninformed about contamination issues were pleased to have the opportunity to talk with a technical person from the ER Project about the specifics of contamination. This exchange was also gratifying to the interviewers.

\section{Impacts of the Laboratory on the Social Structure of the Community}

Eighteen respondents mentioned negative social impacts of the Laboratory, and 10 mentioned positive social impacts. Locating this research facility here a little over 50 years ago has changed social relations. Positive social impacts reported include cultural blending, the Lab's role as an academic model for students, the presence of the scientific community, the high level of education, and the resources that are available from the Lab.

At the same time, some interviewees felt that these factors disrupt the community. There is a sense of racial and class divisions-a Lab versus nonLab dichotomy - which leads to a widening of the social/cultural gap. A related issue, that of Los Alamos versus the surrounding community, must also be kept in mind as the public involvement process evolves. Several Hispanic respondents said that their family roots in this area extend back over 200 years. Some interviewees reported a lack of cultural respect for the community on the part of the Lab and felt that ethnic traditions have been jeopardized by the presence of the Lab. Many interviewers and interviewees alike observed that outreach, not the usual public meeting settings and/or information 
dissemination, has to occur and that the Lab must be sensitive to these concerns.

\section{ISSUES AND CONCERNS ABOUT THE LABORATORY'S ER PROJECT}

\section{Respondents' Awareness and Knowledge of the ER Project}

Twelve of the respondents reported awareness of the ER Project. Eight respondents reported some awareness, and 15 said that they had no or not much awareness of the Laboratory's ER Project. The most frequently mentioned sources of knowledge about the project were newspapers (mentioned 9 times) and friends or family (mentioned 7 times). Other information sources included public meetings, mailings, observation of cleanup activities, and media other than newspapers. One respondent raised the question, "Why isn't the Lab saying more about the ER Project? It would be a positive thing." A clear message emerged that if the public is to play a role in environmental restoration, it needs to be informed of completed and ongoing activities. In addition, interviewees expressed a need to feel a personal connection to the cleanup as a source of motivation to participate.

Interviewees expressed considerable confidence in the ER personnel, but less confidence in the ER Project as an organization and in the Lab, DOE, and government in general. These observations made the interviewing teams feel that going to the public and meeting people was already having positive results. In other words, there was confidence directed toward the individuals who make up the organizations and less confidence in the organizations themselves. Ensuring that pilot project activities reflect this observation will enhance the public involvement process.

Several respondents expressed reservations about their ability to participate in the public involvement process because of their lack of knowledge. Concern about how lay people can participate in decision making on technical matters is an issue for some respondents.

\section{Cleanup Issues}

Interviewers asked, "What cleanup issues cause the most concern for you?" The most frequently mentioned items were health, water, radiation, and waste. Other items mentioned by more than one respondent included managing cleanup efforts, land use, costs, toxins, and air contamination. The response most frequent given (by 21 interviewees) was health. Twelve of the interviewees mentioned general health risks, including concerns abut cancer and long-term effects of Lab activities on health. Nine mentioned radiation and its health effects. Water was mentioned 10 times. Concerns about water ranged from contamination of aquifers to runoff into the Rio Grande. 


\section{Public Involvement in the ER Project's Decision-Making Process}

When the interview turned to the question, "What do you think are the most important things to be considered in setting up an effective public participation process?" respondents offered a variety of thoughtful suggestions. Specific matters raised by interviewees include

- the value of working with existing groups;

- pros and cons of public meetings;

- better communication of scientific information

- tours to provide information in an experiential way (tours have encouraged public involvement at other DOE sites);

- media as avenues for distributing information;

- question and answer sessions, conversations with staff to improve public understanding of ER activities, technologies, successes and failures, etc.; and

- importance of consistency in Laboratory outreach activities.

\section{Working with Existing Groups}

At least half the respondents suggested going to the people to encourage public involvement in the environmental restoration process. They see the area around Los Alamos as rich in organizations and community involvement. Repeatedly, interviewees suggested that ER Project staff meet with existing groups, and some invited project members to meet with groups in which they are involved. One respondent requested periodic meetings in Taos and Santa $\mathrm{Fe}$; another asked that the Lab come to work with communities and attend meetings in rural communities; one person said that the ER Project should go to people "off the hill."

\section{Pros and Cons of Public Meetings}

Most respondents did not favor public meetings for the ER Project. Such meetings were thought to be a less effective way of reaching people than inviting ER personnel to regular meetings of existing groups. Those interviewees who commented on public meetings had some specific suggestions.

Of the respondents who commented on the value of having a facilitator at meetings, most favored having one. One person stated that a facilitator would not be seen as neutral. Other suggestions were 
- set a fixed time limit;

- involve the public in setting the agenda;

- establish the boundaries of the discussion before a meeting and request that people stick to the topics selected;

- value the opinions of people who attend meetings; and

- ask people to submit questions before meetings.

Meeting organizers should ensure that decision makers are present at meetings. Some respondents said that the response, "III have to get back to you on that," was not well received. One respondent noted the importance of clarifying the distinction between public participation and public decision making.

Some respondents saw education as necessary for effective public meetings. One interviewee reported being unwilling to participate without sufficient knowledge. Likewise, the need for more information was a common response. Another common request was for more interaction between ER staff and the public. Over and over again, respondents said, "Hold discussions with our leaders." "Come to our groups." "This exchange is so great." "Being able to ask questions and get answers is so important."

\section{Tours to Provide Information and Encourage Public Involvement}

Several respondents suggested tours of the Laboratory facilities that target community leaders and school children. These tours would include sites undergoing cleanup, sites where cleanup has been completed, science (walking) tours that include presentations on geologic formations and cleanup issues, and even tours that teach participants to identify toxins. Underlying these suggestions was the theme that people in northern New Mexico appreciate and actively enjoy their environment. Using this appreciation as a basis for educating and providing information about cleanup issues can be a useful tool for generating interest in this and other public involvement processes.

\section{Media as Avenues for Disseminating Information}

Most interviewees who were aware of the ER Project got their information from newspapers, yet few suggested newspapers as a reliable source of information. Several respondents said they had little or no trust in the media. Some interviewers found it encouraging that respondents felt there was some slanting in the news about the Laboratory. Some specific suggestions and comments included

- printing a list of clean up sites in the newspaper; 
- preparing videotapes of the area, including potential cleanup sites and the cleanup process;

- using computer networks, including Lab Net, to provide ongoing, up-todate information about ER Project matters;

- using flyers, fact sheets, and a newsletter;

- preparing audiocassettes to help inform and educate the public about cleanup matters;

- preparing educational interactive computer programs for students and public about the ER activities;

- describing issues of particular concern in the ER newsletter (Update); and

- developing a series of newspaper articles written by Lab personnel and citizens about various aspects of environmental restoration, including human interest stories by and about people who worked at the Laboratory in the earlier years.

\section{Communication of Scientific Information}

Many interviewees, without being asked, mentioned the problems that arise in presenting scientific information to the public. Repeatedly, the respondents asked that materials and presentations be in plain language. "Avoid jargon" and "avoid cryptic language and style" were the major themes. People do want explanations of causes and scientific information, but do not want too much technical language.

Some specific suggestions included

- developing graphic presentations of information, perhaps using Laboratory resources to develop visual modeling of the impact of varying cleanup levels at selected sites;

- using science teachers to help present scientific information;

- using the storytelling tradition of the people to communicate environmental restoration information; and

- using Laboratory employees as conduits for information to the public.

Whatever means of presentation are used, people must feel confident in the accuracy of the information.

\section{Conclusions}


In light of both the positive and negative comments, heeding three factors can facilitate public involvement in environmental restoration at the Laboratory. First, because the community believes that the Laboratory is important to the economic well-being of northern New Mexico it will be willing to work toward solutions with the Laboratory. Second, there is considerable trust in the integrity and ability of the individuals working in the ER Project. Third, the community believes the Lab has the technological ability to address the cleanup issues. Also, because the Lab is a research facility, not a production facility, some interviewees believe that it does not have contamination problems on the scale of those at production facilities; however, the interviewers felt that currently most of the public probably does not make this distinction. 


\section{Selected Quotes from Interviews}

"It's not easy to communicate with the Lab, but it's getting better-persistence pays off."

"Can upper management make that leap? Structure of the Laboratory is patriarchal, hierarchical."

"People can take bad news, they can't take lies."

"Honesty is disarming."

"Lab hasn't really cared what the public had to say."

"Heaven knows what's going on now."

"Reality is better than the imagined unknown."

"If questions get answered, people will be satisfied."

"Lack of respect" for other cultures

"Lab has lot of work to do to bring communities back together."

"In northern New Mexico, but has no relation to New Mexico"

"Los Alamos is a foreign country."

"We're in this together, whether or not we want to be."

"Important for Lab to listen to what people have to say, "don't always come with answers."

"Lab has opened windows and doors to public," inviting participation; therefore, difficult, if not foolish, to try to hide anything.

"You have to decide what you [ER or Lab?] want them to know."

Perception is that we're "going through the motions only" at public meetings.

"All you know is what you hear on the news."

Some interviewers' comments:

"Thanks for keeping us in the loop by letting us review the draft report."

"Talking to the public should be part of our job, once a week." 
"A lot of excitement was generated during these interviews."

"Conversations really made people (interviewers and interviewees) feel good." 


\title{
APPENDIX B
}

\section{SELECTED ANNOTATED REVIEW OF PUBLIC PARTICIPATION PLANS AND ACTIVITIES AT OTHER INSTITUTIONS}

\author{
Merle Lefkoff \& Associates
}

\begin{abstract}
An Overview of Efforts to Develop a Decision Support Methodology for Selection of Future Land Use Scenarios to Be Evaluated in Environmental Restoration Program Risk Assessments (DOE 1992)
\end{abstract}

This report emphasizes the importance of land use recommendations in the overall ER Program. It states, "The process of selecting reasonable and defendable future land use scenarios should begin during the scoping and planning phase of environmental restoration projects." The report gives regulatory overviews, as well as EPA policy and guidance. The program's primary aim is to provide information to the public on future land use scenarios. Only selected personnel in DOE's Environmental Restoration Program, rather than the public, are involved in decision making.

Public Involvement in the ER Project at Los Alamos National Laboratory (Myer and Lefkoff and Associates 1994)

This rough draft, which describes the development of a public participation strategy for the Laboratory's ER Project includes

- a description of process, which includes asking for public input at the planning stage of developing a public participation plan. The draft draws from risk management literature, which suggests identifying the public's thinking about risk management and adapting materials and presentations for public consumption accordingly. The section also suggests that the public be asked to evaluate the ER Project's communication techniques.

- use of a pilot project. The draft points out that a pilot project might be useful because "we do not believe that stakeholders will be interested in philosophical discussions of alternate decision-making methodologies; rather, they will be interested in having an impact on decisions. In other words, stakeholders must be involved in decisions that are immediately important to them and that they can affect."

- asking the public how it wishes to participate. The draft says, "We realize that our approach to public involvement (asking the public how they wish to participate) is likely to be time consuming. However, we believe that this approach is justified for two reasons. First, building trust takes time, and second, it supports DOE public participation policy." 
- obtaining the public's assumptions about future land use for risk management and their evaluation of the pilot project

\section{The Future for Hanford: Uses and Cleanup: Summary of the Final Report of the Hanford Future Site Uses Working Group (Hanford Future Site Uses Working Group, December 1992)}

DOE, EPA, other federal agencies, local and state governments, and tribal representatives established an crganizing committee to set up a Future Site Uses Project at Hanford. This committee began its work with the premise that a fair process was needed to bring the different parties together to discuss their future visions for the Hanford site.

The working group, which convened in April 1992, was charged with three related tasks:

- examine Hanford and identify a range of potential future uses for the site,

- select appropriate cleanup scenarios necessary to make these future uses possible in light of potential exposure to contamination, if any, after cleanup, and

- investigate all the cleanup scenarios developed by the group to establish priorities for conducting the cleanup at Hanford.

During an initial two-day session, the working group agreed on a charter and ground rules to guide the group process. The process included dividing the Hanford Reservation into six geographic areas and analyzing the problemsboth those that were unique to individual geographic areas and those shared by all six areas - by inviting staff presentations and touring the facility. As a result, the group proposed development of a baseline that would include the following kinds of information:

- history that gave rise to the current situation at Hanford;

- parameters for release of land in the future;

- location, nature, and extent of known contamination and remedial technologies; and

- list of the many decisions that affect each site.

The working group then divided into four small groups to address particular cleanup problems at the Hanford site. These small groups identified future land use options and drafted cleanup scenarios. In October of 1993, the working group published a final report, which included its recommendations.

Revised Community Relations Plan for Lawrence Livermore National Laboratory, Livermore Site" (Lawrence Livermore National Laboratory 1993) 
The original community relations plan for Lawrence Livermore National Laboratory (LLNL) was prepared in 1989 with limited public involvement. Subsequently, Livermore decided to obtain more public input, which occurred in November and December of 1992, and revised the plan, based on that input, in 1993. The groups involved in the discussions were

- Community Work Group (CWG) members,

- former CWG members,

- past attendees of CWG meetings,

- Lawrence Livermore National Laboratory (LLNL) staff and management,

- LLNL employees,

- business representatives,

- public interest groups, and

- LLNL neighbors, elected officials, and city and county representatives.

The revised community relations plan provides information and describes activities on the LLNL site. The information most relevant to issues at Los Alamos comes from a survey conducted in 1992. The survey was conducted to determine

- the public's extent of knowledge of Superfund problems and history at LLNL,

- concerns about the site and attitude toward cleanup,

- types and effectiveness of communication,

- extent of public contact with site officials,

- attitudes about the CWG and recommendations for improvement, and

- contact with LLNL staff and activities that were and were not effective in describing the cleanup.

The concerns expressed by the survey respondents fell primarily into five categories:

- LLNL's approach to the cleanup and cleanup methods used,

- communications and community relations,

- health and environmental issues, including risks posted by contaminants,

- long-term funding and administration of the project, and

- other laboratory activities.

The Community Relations Program developed several objectives as a result of the interviews:

- conduct a dialogue with the public on the cleanup yet to be conducted,

- maintain contact with the public and CWG,

- provide information in an accurate and timely manner,

- invite public evaluation of program progress,

- respond to information needs of elected officials, etc.,

- respond to community concerns and interests that came out of this process. The Community Relations Plan was revised in order to reflect 
real community concerns and to specify directions for the cleanup program.

The activities in the revised plan were based largely on the results of an assessment survey to re-evaluate past community relations activities. Many of the responses focused on LLNL's improved attitudes and approach to interacting with the public, concern that there be continued public involvement processes, and concern about adequate funds for the cleanup. LLNL received specific positive feedback on having simplified the language used in informational materials, conducting site tours, and replacing presentations with more dialogue and informality at meetings. Areas in which-the public still wanted improvement included expanding the number of categories of persons involved, sustaining interest among persons involved, and ensuring that predecisional input is used to develop new ways of interacting with the public.

\section{Handbook for Conducting Community Relations Activities in the Superfund Program (EPA 1988)}

The EPA issued this handbook as policy and guidance for conducting community relations under the Superfund act. The handbook describes policy requirements for community relations programs and techniques and guidance to implement the policies. The objectives specified in the handbook are to

- give the public the opportunity to provide input on technical decisions,

- inform the public of planned and ongoing actions, and

- focus on and resolve conflict.

The handbook gives one chapter on setting up a community relations program (Chapter 3, "Conducing Community Interviews and Designing Community Relations Programs for Remedial Responses"). Chapter 3 explains in detail two critical steps in planning a community relations program for Superfund remedial action:

- conducting community interviews, to identify representative members of the affected public, their concerns, and the best means to involve and communicate with the public; and

- developing a site-specific community relations plan, based on the needs expressed by the community during community interviews, which specifies the types of community relations activities to be conducted during remedial action.

The process to be followed includes

- conducting community interviews on which to base selection of members of a community relations committee,

- developing a community relations plan,

- establishing public information repositories, 
- proposing a plan for remedial action on sites,

- obtaining public comment on proposed plans,

- providing a responsiveness summary,

- explaining differences of opinion on remedial action,

- notifying the public of selection of remedy,

- revising the plan after public comment, and

- providing a fact sheet and notification on engineering design.

\section{A Discussion with the Fernald Environmental Restoration Management Company (Lefkoff and Associates 1993)}

DOE and the Fernald Environmental Restoration Management Corp. initiated the Envoy Program to promote one-on-one communication between Fernald personnel and local community groups in the area. The program was designed to (1) facilitate two-way communication and (2) "improve the decisionmaking process at Fernald by building closer relationships with numerous stakeholder groups." Key to the program is to get public input to improve decisions before final decisions are made.

Some of the program's guiding principles are

- The public is not monolithic but comprises many different individuals and groups.

- The Fernald Citizens' Task Force provides public input into decisions, but a larger and more diverse representation is necessary to ensure broader public awareness and direct involvement of all "our publics" in the Fernald decision-making process.

- The primary goal is to build closer relationships with the broadest possible range of groups.

An early evaluation reports that

- "The biggest accomplishment for several envoys has simply been to develop the personal relationship with their assigned stakeholder group(s).

- Gaining trust and confidence from stakeholders continues to be the greatest challenge.

- Stakeholders have gained confidence that real cleanup efforts are occurring that have changed the way the public views Fernald.

- Several stakeholder groups are now helping Fernald reach farther into the community."

On October 13, 1994, DOE and officials of Fernald Environmental Restoration Management Corp. held a formal public meeting at which they received 17 written comments, most of which accepted the preferred alternative for cleaning up the waste pits. Fernald continues to pursue the Envoy Program vigorously. 


\section{Health Studies on Rocky Flats (Colorado Department of Public Health and Environment 1991)}

With funding provided by DOE, the State of Colorado is assessing the off-site risk to surrounding communities resulting from activities at the Rocky Flats plant. An extensive public involvement program was developed at the first stage of the risk assessment, the stage in which the state was trying to revised its original estimates of doses to the public that might have occurred as a result of past releases. The program, which is ongoing, involves several steps, including the following, which are currently being implemented:

- training personnel from the Colorado Department of Health and Environment to understand and implement public involvement;

- training members of the Rocky Flats Health Advisory Panel, which includes scientists and members of the public, to facilitate public meetings;

- setting up a public meeting format that encourages citizens to have direct dialogue with members of the advisory panel at small round tables;

- sending out a people-oriented quarterly newsletter full of photos and graphics and to update the studies;

- making available "citizen summaries" of all technical documents; and

- funding a Citizens' Environmental Sampling Committee to test 26 soil samples from sites selected by the committee, providing an opportunity for citizens to get directly involved in the program.

\section{EDB: A Case Study in the Communication of Health Risk (EPA 1985)}

This case study shows that communicating with the public is an extremely difficult process. The report describes EPA's efforts to communicate with the public about the risks of EDB (ethylene dibromide) and what information the public actually received through the media. Although special in many ways, the EDB case shows the problems regulatory and cleanup agencies have when they must take regulatory actions and assure the public that the risks in question are being dealt with adequately. Above all, the case study shows that communication alone is not sufficient to build trust in the community. This case also shows a major information barrier that agencies face when their belief of "how safe is safe" is different from the public's belief.

The authors of the study concluded that "The problem of conveying risk issues to the public, although a very complicated matter, can be stated simply. Risk assessment uses techniques, has a perspective, and has objectives determined by the mandate of the regulatory agency. It is unlikely that an agency has ever been directed to translate the results of its risk assessment into terms that the public can understand more clearly by answering the question What does all that mean to me, personally?' The best-managed regulatory scheme has rough going when faced by a public that is confused and, as a result, antagonistic." 


\section{Managing Water-Related Conflicts (Viessman and Smerdon 1990)}

Two chapters are described in this summary: those written by Bingham and Orenstein and Lefkoff and Associates. The former gives a summary of the history of mediation in environmental conflicts, followed by advice on creating efficient and effective problem-solving processes that appear to have application for cleanup problems. The latter walks the reader through a case study of a public dispute in Colorado that used an advisory committee to reach agreement among diverse stakeholders on a regulatory process for moving the public process forward.

\section{How I Turned a Critical Public into Useful Consultants (Johnson 1993)}

This document is a testimonial to public involvement in which Johnson describes his activity with the Bonneville Power Administration (BPA). First, the BPA tried public meetings and then hired a consultant to assess its program. In spite of these moves, the public still perceived BPA to be arrogant, insensitive, and uncaring. Johnson then undertook two tasks: change the attitude of BPA and develop its practical skills in working with the public. He states, "Just when it began to seem that BPA was doomed to a future of litigation and hostility, we made an important discovery. We found that by inviting the public to participate in our decision-making process, our adversaries helped us make better decisions. By involving the public in the decision-making process itself, we gained authority and legitimacy, avoided costly lawsuits and political challenges, and arrived at creative solutions to seemingly intractable problems. Overall, our policy making improved."

\section{Public Involvement Techniques: A Reader of Ten Years Experience at the Institute for Water Resources (Creighton et al. 1983)}

The Institute for Water Resources has been a pioneer in public involvement for many years, and this compendium presents in great detail a model for evaluating public participation programs. The authors explore many facets of public involvement as it has been applied in the field, which is what makes the reader is so valuable. Three of the chapters describe the Sanibel Island experience, which detail a public involvement program, present the methodology by which the program was evaluated, give the results of the evaluation, and explain the cost/benefit analysis applied to the results of the program. 


\section{REFERENCES}

Colorado Department of Public Health and Environment 1991. "Health Studies on Rocky Flats,"

Volume 1, Number 1, 4210 E. 11th Avenue, Denver, Colorado 80220.

DOE (US Department of Energy) , July 28, 1992. "An Overview of Efforts to Develop a Decision Support Methodology for Selection of Future Land Use Scenarios to $\mathrm{Be}$ Evaluated in Environmental Restoration Program Risk Assessments," The Office of Southwestern Area Programs, Department of Energy, Washington, DC.

EPA (US Environmental Protection Agency), June 1988. "Community Relations in Superfund-A Handbook," EPA/540/R-92/009, OSWER Directive 9230.0-3B, Washington, DC.

EPA (Environmental Protection Agency), January 9, 1985. "EDB: A Case Study in the Communication of Health Risk, "Washington, DC.

Hanford Future Site Uses Working Group, December 1992. The Future for Hanford.: Uses and Cleanup: Summary of the final report of the Hanford Future Site Uses Working Group, Environmental Data Management Center, Westinghouse/Hanford Co., Richland, Washington.

Creighton, J., J. D. Priscoli, and C. M. Dunning, May 1993. "Public Involvement Techniques: A Reader of Ten Years' Experience at the Institute for Water Resources," IWR Research Report 82-RI, Institute for Water Resources, US Army Corps of Engineers, Ft. Belvoir, Virginia.

Johnson, P. J., January-February 1993. "How I Turned a Critical Public into Useful Consultants," in Harvard Business Review, No. 93103.

Lawrence Livermore National Laboratory, June 1993. "Revised Community Relations Plan for the Lawrence Livermore National Laboratory, Livermore Site," Lawrence Livermore National Laboratory, Livermore, California.

Lefkoff and Associates 1993. "A Discussion with the Fernald Environmental Restoration Management Company," Santa Fe, New Mexico

Meyer, M., and Lefkoff and Associates, January 13, 1994. "Public Involvement in ER Project at Los Alamos National Laboratory," draft, Los Alamos National Laboratory, Los Alamos, New Mexico.

Viessman, W., Jr., and E. T. Smerdon (Eds.), November 1989. "Managing Water-Related Conflicts," Proceedings of the Engineering Foundation Conference, Santa Barbara, California, November 5-10, 1989, American Society of Civil Engineers, New York, New York. 